\title{
Embryonic development of a mountainous fish species Garra cambodgiensis (Tirant, 1883) in southern Thailand
}

\author{
Supaporn Sutin • Fahmida Wazed Tina (iD \\ email: asuparporn@yahoo.com
}

${ }^{\text {A}}$ Faculty of Science and Technology, Nakhon Si Thammarat Rajabhat University, Nakhon Si Thammarat 80280, Thailand.
${ }^{\mathrm{B}}$ Language Center, Nakhon Si Thammarat Rajabhat University, Nakhon Si Thammarat 80280, Thailand.

Received: December 14, 2019 - Accepted: January 19, 2020 • Published Online: February 04, 2020

\begin{abstract}
This study examined the artificial breeding and embryonic development of a mountainous fish species Garra cambodgiensis (Tirant, 1883) found in Promlok waterfall in Khaoluang National park, Phromkhiri district, Nakhon Si Thammarat province. The fishes were collected from June 2017- January 2018 and kept in aquaria. Afterward, the brood males and females were selected and injected with buserelin $\left(\mathrm{LHRH}_{\mathrm{a}}\right)(10 \mu \mathrm{g} / \mathrm{kg}$ body weight $)$ and domperidone $(10 \mathrm{mg} / \mathrm{kg}$ body weight). After the injections, both females and males were kept together in the water at a proportion of 3 females: 1 male. The fertilization of eggs started after 4 hours and 30 minutes. The fertilized eggs were greenish-grey and semibuoyant. After fertilization, one blastodisc turned into 2 equalsized blastomeres, and then each cell divided into 4, 8, 16, 32, 64 cells respectively. The morula stage went to the blastula stage in about $3 \mathrm{hr}$ and $28 \mathrm{~min}$, to gastrula stage in about $5 \mathrm{hr}$ and $11 \mathrm{~min}$, and to the somite stage in about $7 \mathrm{hr}$ and $7 \mathrm{~min}$. The optical vesicles and auditory vesicles developed after approximately $8 \mathrm{hr}$ and $27 \mathrm{~min}$, and $10 \mathrm{hr}$ and $30 \mathrm{~min}$, respectively. After approximately 12 hours and 58 minutes of fertilization, hatching of eggs occurred. Nowadays, the numbers of $G$. Cambodgienesis are declining rapidly in southern Thailand due to several environmental and anthropogenic reasons. Therefore, it is very important to conserve the populations of $G$. Cambodgienesis. Artificial breeding could be an effective way to conserve and restore this fish in their natural habitat in southern Thailand.
\end{abstract}

Keywords: artificial breeding, fish conservation, developmental stages of embryos, Khaoluang National park, Promlok waterfall, stone lapping minnow

\section{Introduction}

Garra cambodgiensis (Tirant, 1883) are freshwater fish and are belong to the family of Cyprinidae. They are small-bodied $(4-10 \mathrm{~cm})$ fish and inhabit rocky bottoms of fast- flowing water in small- and medium-sized streams (Jaisuk and Senanan 2018a). They are widely distributed in Southeast Asia (especially in Chao Phraya basin and Mekong basin (Lothongkham 2008; Kulabtong and Mahaprom 2016)), Southern China, India, Middle East and northern and central Africa (Kullander and Fang 2004). In Thailand, $G$. cambodgiensis are found in Nan river drainage basin in northern Thailand (Jaisuk and Senanan 2018ab), watersheds in eastern region in central Thailand (Beamish et al 2006), cyber stream in west Thailand (Kulabtong and Mahaprom 2016), and several river sources at the waterfalls (e.g., Krungching waterfall, Promloke waterfall, Aay-khiew waterfall, and Karom waterfall) in southern Thailand (personal observation by S. Sutin).

G. cambodgiensis can easily be identified by their slightly curved dorsal fin, broad mid-lateral stripe, two black bands on the dorsal fin, plain caudal fin, or with dark margins, and well-developed tubercles on the snout (see Mazlan et al 2007). Due to their elongated bodies, they can stay in fastflowing currents. They are able to cling to rocks by using their mouth, which acts as a sucker. They move to floodplains or paddy fields for breeding during rainy and flooding seasons, nurse their larvae until they become juveniles, and afterward, they return to the streams. G. cambodgiensis is a strictly herbivorous fish species, and they feed on algae and other aquatic plants (Mazlan et al 2007).

Nowadays, G. cambodgiensis is heavily exploited in Nakhon Si Thammarat province in southern Thailand as they are important food resources for local people. Moreover, due to their small body, they may be easily affected by several factors of their habitats such as the presence of barriers, the complexity of a stream barrier, and habitat fragmentation (Neville et al 2006; Sterling et al 2012; Pilger et al 2017). Because of these reasons, their number is declining day by day. Therefore, it is crucial to conserve and restore the wild populations of this tropical stream fish. Artificial breeding could be an option to conserve this fish species. This study 
aims to conduct artificial breeding of G. cambodgiensis, and to observe the developmental stages of the embryos in Nakhon Si Thammarat province, southern Thailand. Previously only one study (Termvidchakorn et al 2016) observed the larval development of G. cambodgiensis in northern Thailand. It is essential to mention that most of the studies on $G$. cambodgiensis have been conducted in northern Thailand (Pornsopin et al 2004; Termvidchakorn et al 2016; Jaisuk and Senanan 2018ab). There is a lack of study conducting in southern Thailand. This study is the first one to focus on artificial breeding and embryonic developmental stages of $G$. cambodgiensis in southern Thailand.

\section{Materials and Methods}

Study site and data collection

Garra cambodgiensis fishes were randomly caught from Promloke waterfall in the Khaoluang National Park $\left(8.4942^{\circ} \mathrm{N}\right.$ and $\left.99.7300^{\circ} \mathrm{E}\right)$, Phromkhiri district, Nakhon Si Thammarat province (Figure 1). This waterfall is about $5 \mathrm{~km}$ far from the district office of Nakhon $\mathrm{Si}$ Thammarat city. The fishes were collected from June 2017 January 2018. After collection, the fishes were taken to the Freshwater Breeding Center of the Faculty of Science and Technology in Nakhon Si Thammarat Rajabhat University, Nakhon Si Thammarat province and kept in aquaria. The weights and standard lengths of fishes were 8.92-19.60 $\mathrm{g}$ and $6.30-12.30 \mathrm{~cm}$, respectively.

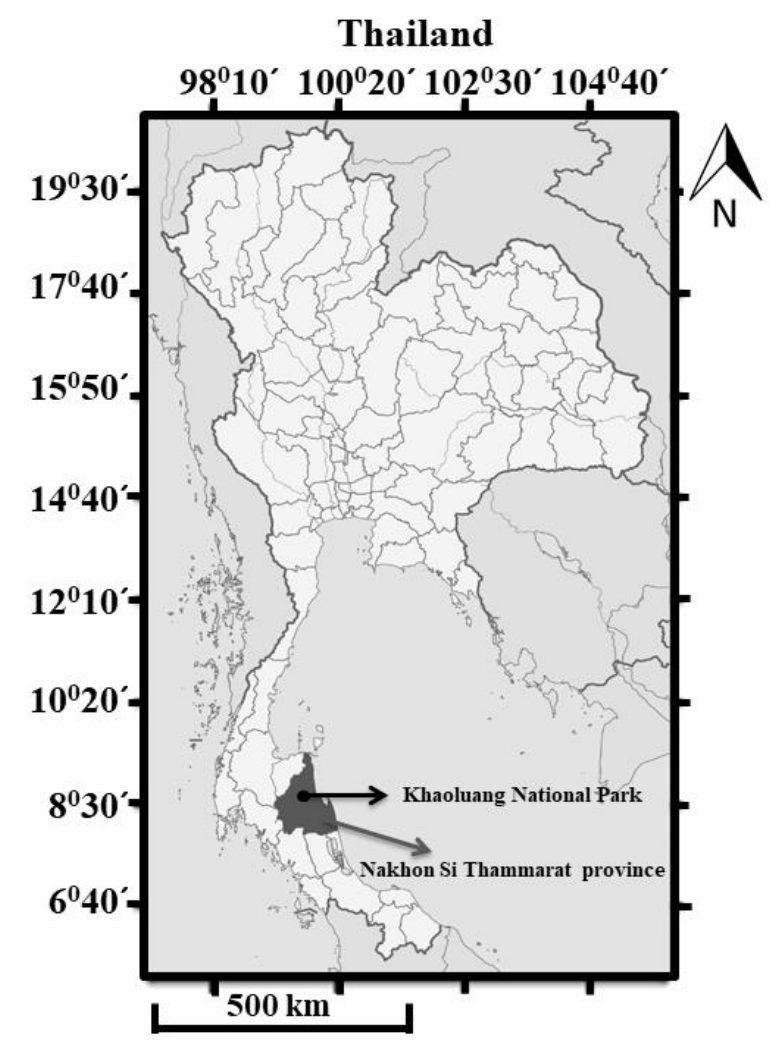

Figure 1 Location of Nakhon Si Thammarat province and Khaoluang National park inside Thailand map.

The selection of brood males and females of Garra cambodgiensis and artificial breeding

Brood males and females of Garra cambodgiensis were selected from the randomly collected fishes based on several characteristics. Sexually matured males and females develop tubercles on the head and snout when they are ready to breed. Usually, these tubercles are more prominent in males than in females, and males tend to have a slimmer body than females. Moreover, brood males have a long pelvic fin that nearly reaches the anal fin. When the belly of brood males is pressed, some milky seminal fluid comes out. The female broods of $G$. cambodgiensis are larger and generally have more swollen belly compared to males (Figure 2). The pelvic fin of brood females reaches genital pore. After the selection of broods, they were injected with $10 \mu \mathrm{g} / \mathrm{kg}$ buserelin acetate $\left(\mathrm{LHRH}_{\mathrm{a}}\right)$ in combination with $10 \mathrm{mg} / \mathrm{kg}$ domperidone (Pornsopin and Joradol 2006). Afterward, males and females were kept together in flowing water at a proportion of 3 males: 1 female for spawning. When they finished spawning, their fertilized eggs were studied to examine their developmental stages. Artificial breeding of Garra cambodgiensis was conducted from October, 2017 to January, 2018 (rainy season in southern Thailand). 

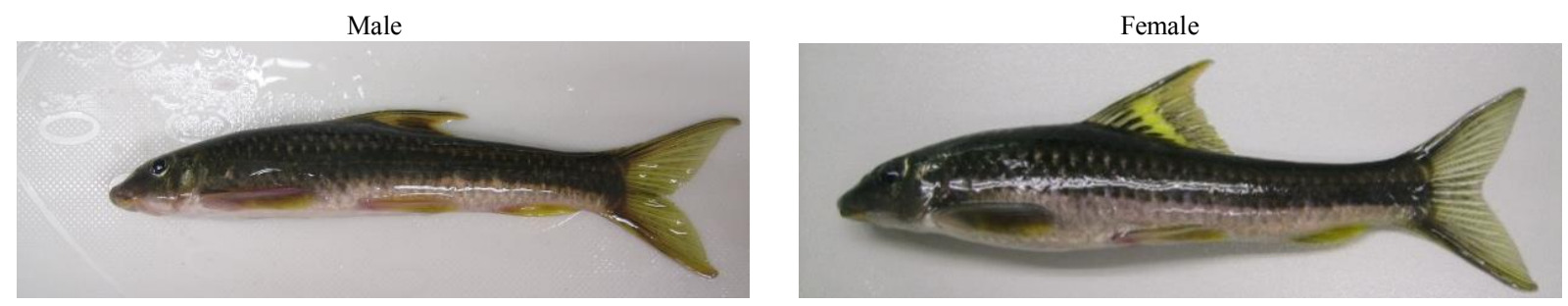

Figure 2 Brood male (left) and female (right) of Garra cambodgiensis.

\section{The study of embryonic development}

The fertilized eggs were collected and examined with an ocular micrometer (40x magnification). Then each developmental stage was observed and recorded. Their development stages were recorded as cleavage, blastula, gastrula, organogenesis, and body development based on Rainboth (1996) and Pornsopin and Joradol (2006).

\section{Water quality}

During the hatching of Garra cambodgiensis, several water quality parameters (temperature, $\mathrm{pH}$, dissolved oxygen, total ammonia, nitrite, and hardness) were measured. Temperature was measured using a Celsius thermometer and $\mathrm{pH}$ was measured by a digital $\mathrm{pH}$ meter (Jenway 3020). Dissolved oxygen was measured by a digital DO-meter (YSI, model 158). Total ammonia, hardness, and nitrite were measured using APHA standard methods (APHA 1998) (Islam et al 2004). We observed that temperature was 29-30 ${ }^{\circ} \mathrm{C}, \mathrm{pH}$ was 6.50 , dissolved oxygen was $6.00 \mathrm{mg} / \mathrm{L}$, total ammonia was $0.00 \mathrm{mg} / \mathrm{L}$, nitrite was $0.10 \mathrm{mg} / \mathrm{L}$ and hardness was $68.00 \mathrm{mg} / \mathrm{L}$.

\section{Results}

\section{Embryonic development of Garra cambodgiensis}

Garra cambodgiensis eggs were greenish-gray in color and semi-buoyant. After being fertilized, the eggs became swollen as they were filled with fluid. A newly fertilized egg stayed in zygote period until it went to the first cleavage. The yolky end of an egg (vegetal pole) remained homogenous while the other end (animal pole) went to cell division. Cleavage occurred in the blastodisc, which is a region of the yolk-free cytoplasm at the animal cap. The cleavage started approximately 42 minutes after fertilization. In fish eggs, the cytoplasmic divisions are meroblastic, where the blastodisc is cut in the middle to divide into two blastomeres of equal size. Afterward, each cell started to divide itself and they lay parallel with the old ones. These 4 cells were equal in size. Afterward, these 4 cells turned into 8 cells (Figure $3 \mathrm{a}$ ). The zygote developed 16 cells within 50 minutes, 32 cells within 58 minutes, and 64 cells within 1 hour and 6 minutes after the fertilization (Figure $3 \mathrm{~b}$ and $3 \mathrm{~d}$ ). After 1 hour and 21 minutes of fertilization, the blastodisc looked like a mulberry (cell cluster) in appearance at the animal pole. The blastodisc in this stage consisted of three or four cell payers. The blastomeres were almost equal in size and were spherical or polygonal in shape. The embryo in this stage is known as a morula (Figure 3e).

After the cleavage, a narrow cavity was observed between the blastodisc and the yolk. The blastodisc flattened and produced a blastoderm that started to cover the yolk. The surface of the yolk was covered by a thin layer that is called a periblast. Blastocoel was observed between periblast and blastoderm. The embryo in this stage is known as a blastula (Figure 3f). It took 3 hours and 28 minutes to form the blastocoel after the fertilization.

In the gastrula stage, the blastoderm cells covered the yolk completely. In this stage, ectoderm, mesoderm, and endoderm of an embryo formed within 5 hours and 11 minutes after fertilization (Figure $3 \mathrm{~g}$ ).

In the somite stage, the mesoderm started to modify, which later developed into bones and muscles. In this stage, the embryo elongated and first body movement appeared. The embryos went in the somite stage after 7 hours and 7 minutes of fertilization (Figure $3 \mathrm{~h}$ ). In embryos, the auditory vesicle formed, and the heart started working after 10 hours and 30 minutes of fertilization (Figure $3 \mathrm{i}$ and $3 \mathrm{j}$ ). Its brain developed and body started shaking after 11 hours and 23 minutes of fertilization (Figure 3k). Just before hatching, the egg shells shrank and the larvae hatched out. The newly hatched juveniles were about $3 \mathrm{~mm}$ long. Their skins were thin and transparent. Hatching occurred about 12 hours and 58 minutes later of egg fertilization (Figure 31). All of this information are provided clearly in Table 1 .

\section{Characteristics of larvae of Garra cambodgiensis}

The bodies of pre-larvae were elongated. They did not have any pigment until they were $4 \mathrm{~mm}$ in length. The bodies of post-larvae were also elongated, but they had pigments on their head and body (both the dorsal and ventral parts of the body). They possessed dark stripes on their snout, operculum and body. 


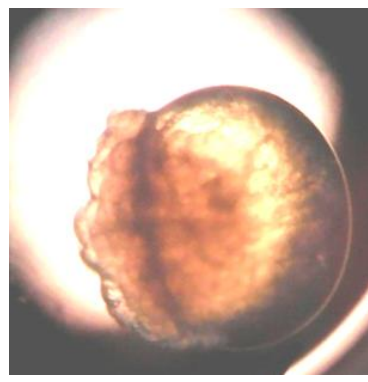

(a) 8 cells; $42 \mathrm{~min}$

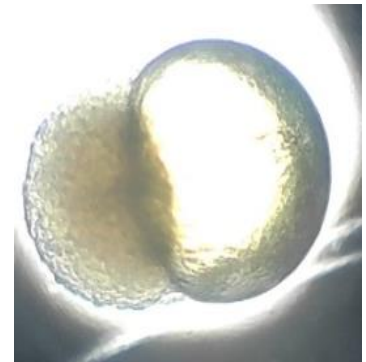

(d) 64 cells;

$1 \mathrm{hr}$ and $6 \mathrm{~min}$

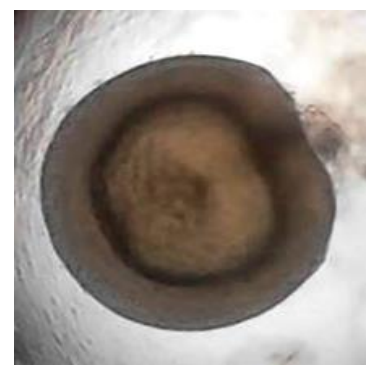

(g) gastrula;

$5 \mathrm{hr}$ and $11 \mathrm{~min}$

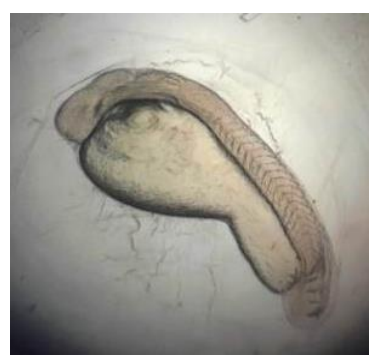

(j) auditory vesicle; $10 \mathrm{hr}$ and $30 \mathrm{~min}$ $\vdash \mathrm{mm}$

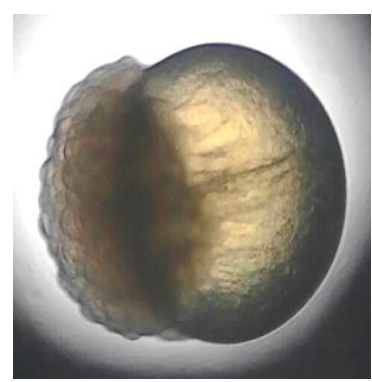

(b) 16 cells; $50 \mathrm{~min}$

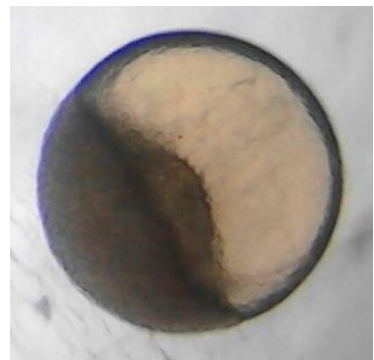

(e) morula;

$1 \mathrm{hr}$ and $21 \mathrm{~min}$

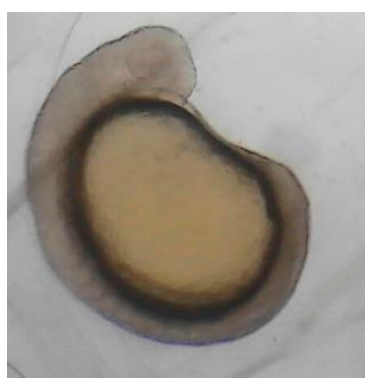

(h) somite stage;

$7 \mathrm{hr}$ and $7 \mathrm{~min}$

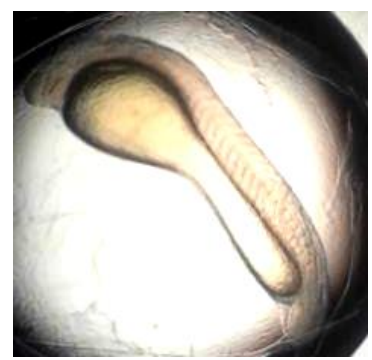

(k) body movement; $11 \mathrm{hr}$ and $23 \mathrm{~min}$

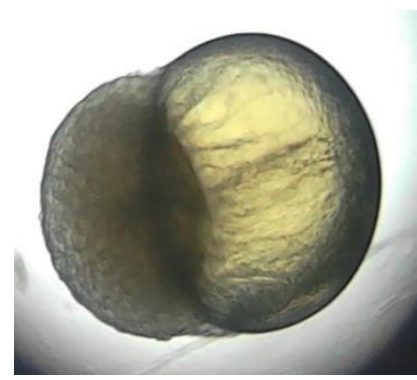

(c) 32 cells; $58 \mathrm{~min}$

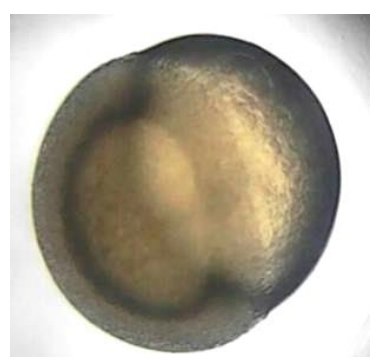

(f) blastula; $3 \mathrm{hr}$ and $28 \mathrm{~min}$

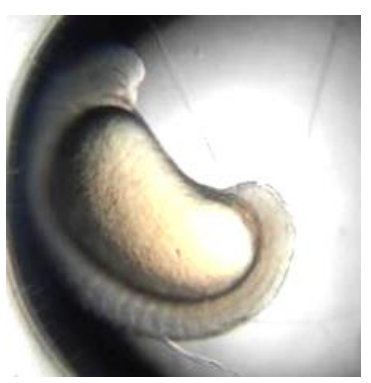

(i) optic vesicle;

$8 \mathrm{hr}$ and $27 \mathrm{~min}$

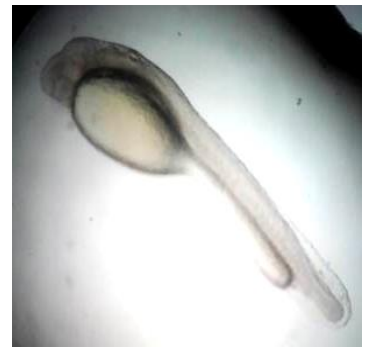

(1) hatch out;

$12 \mathrm{hr}$ and $58 \mathrm{~min}$

Figure 3 Embryonic developmental stages of the fertilized eggs of Garra cambodgiensis. 
Table 1 Embryonic development of Garra cambodgiensis.

\begin{tabular}{|c|c|c|}
\hline Duration of post fertilization & Figure number & Stages of Embryonic development \\
\hline $42 \mathrm{~min}$ & $3 a$ & The zygote divides into 8 cells by the process of mitosis. \\
\hline $50 \mathrm{~min}$ & $3 b$ & The zygote divides into 16 cells. \\
\hline $58 \mathrm{~min}$ & $3 \mathrm{c}$ & The zygote divides into 32 cells. \\
\hline $1 \mathrm{hr}$ and $6 \mathrm{~min}$ & $3 d$ & The zygote divides into 64 cells. \\
\hline $1 \mathrm{hr}$ and $21 \mathrm{~min}$ & $3 \mathrm{e}$ & In the morula stage, blastoderm develops. \\
\hline $3 \mathrm{hr}$ and $28 \mathrm{~min}$ & $3 f$ & In the blastula stage, blastocoel forms between blastoderm and periblast. \\
\hline $5 \mathrm{hr}$ and $11 \mathrm{~min}$ & $3 g$ & $\begin{array}{l}\text { During the gastrula stage, the early embryonic development occurs and } \\
\text { three germ layers (ectoderm, mesoderm and endoderm) form. When } \\
\text { these three-layered structures are grown up, the head and body of the } \\
\text { embryo develop. }\end{array}$ \\
\hline $7 \mathrm{hr}$ and $7 \mathrm{~min}$ & $3 \mathrm{~h}$ & $\begin{array}{l}\text { During the somite stage, mesoderm is modified which gives rise to } \\
\text { muscles and bones of the embryos. }\end{array}$ \\
\hline $8 \mathrm{hr}$ and $27 \mathrm{~min}$ & $3 \mathrm{i}$ & Optic vesicles develop. \\
\hline $10 \mathrm{hr}$ and $30 \mathrm{~min}$ & $3 \mathrm{j}$ & Auditory vesicles develop and heart starts working. \\
\hline $11 \mathrm{hr}$ and $23 \mathrm{~min}$ & $3 \mathrm{k}$ & Their brain is visible. \\
\hline $12 \mathrm{hr}$ and $58 \mathrm{~min}$ & 31 & $\begin{array}{l}\text { The larvae shake wildly until the egg shell shrinks. Then the larvae } \\
\text { hatch out. These newly-hatched fish larvae are about } 3 \mathrm{~mm} \text { in length. } \\
\text { Their skins are thin and transparent. }\end{array}$ \\
\hline
\end{tabular}

\section{Discussion}

This study shows the artificial breeding of Garra cambodgiensis which is possible in southern Thailand. Therefore it could be possible to conserve and restore the populations of G. cambodgiensis in their natural habitat. Our work highlights the characteristics and embryonic developmental stages of $G$. cambodgiensis found in Khaoluang National park, Nakhon Si Thammarat province. The characteristic of each developmental stage was observed closely and recorded (see Table 1).

It was found that the eggs of $G$. cambodgiensis hatched 12 hours and 58 minutes later of fertilization when the temperature was $29-30{ }^{\circ} \mathrm{C}$. Pornsopin et al (2004) observed that eggs of G. cambodgiensis hatched 15-16 hours later of fertilization in Chiang Mai province, Thailand, when the temperature range was $25-29^{\circ} \mathrm{C}$. Another study (Joradol and Pornsopin 2006) observed that eggs of another species of Garra (G. fuliginosa) hatched 15 hours and 48 minutes later of fertilization when the temperature was $29-31^{\circ} \mathrm{C}$. The reason behind the shorter hatching time in our study could be the narrower range of water temperature $\left(29-30{ }^{\circ} \mathrm{C}\right)$.

We observed that pre-larvae of $G$. cambodgiensis contained no pigment until they were $4 \mathrm{~mm}$ long, but the postlarvae had pigments on their head and body. Similarly, Termvidchakorn et al (2016) observed chromatophore pigments on the head and body of the larvae in $G$. cambodgiensis, and based on the position of the pigment, they identified the larvae of G. cambodgiensis. According to Termvidchakorn et al (2016), the presence of pigments on different parts of the body of Garra larvae is significant to identify the species.

There are 140 species of Garra worldwide, but only seven species are found in Thailand (Smith 1945; Vidthayanon et al 1997) those are heavily exploited nowadays. Moreover, several environmental and anthropogenic factors are affecting them and they are declining day by day. Among several environmental factors, temperature, $\mathrm{pH}$ and conductivity have direct and indirect effects on reproduction and survival of fish populations (see Gebrekiros 2016). Temperature is the one factor that may directly and/or indirectly affect the physiology and behaviour of fish species, as well as limit the range of those fish species (Cravens 1982; Taylor et al 1993). Beamish et al (2006) observed that temperature fluctuations affected the distribution of cyprinid fish species in Thai waters. In stream waters, if temperature exceeds the maximum temperature tolerance of a fish species, there is a high possibility that the fish species may disappear from that stream (Eaton and Scheller 1996). The thermal regimes of streams would change due to global warming (an increase of temperature due to increase of carbon dioxide and other greenhouse gases in atmosphere) and it is quite likely that the higher temperature would exceed the maximum temperature tolerance of stream fish species (see Mohseni et al 2003). Anthropogenic factors 
such as overexploitation, land and industrial development, and inputs of chemical contaminants in waters are responsible for declining of fish populations in their natural habitat through producing ecological and genetic effects (Johnson et al 1998; Lande 1998). Therefore, it is essential to conserve Garra spp. before they enter into the red list of IUCN. Artificial breeding and restocking of fish in their natural habitat could be one of the options to conserve these fish species.

\section{Conclusions}

This study shows the artificial breeding and embryonic developmental stages of Garra cambodgiensis in southern Thailand for the first time. Until now, due to a lack of knowledge of their artificial breeding, it was not possible to conserve this species in southern Thailand but based on this study, it would be possible to conserve G. cambodgiensis. Only artificial breeding might not be enough to conserve and restore the Garra spp, and it is required to control fishing gear and overfishing. The government should take initiatives to increase the awareness of people regarding biodiversity conservation. Further research can be conducted on embryonic and larval development stages of some other indigenous fish species in southern Thailand to conserve them.

\section{Acknowledgements}

This study was financially supported by the Faculty of Science and Technology in Nakhon Si Thammarat Rajabhat University. We are thankful to the villagers living near Promloke Waterfall, Nakhon Si Thammarat province, for collecting Garra cambodgiensis.

\section{Conflict of Interest}

The authors declare no conflict of interest.

\section{References}

American Public Health Association (APHA), American Water Works Association, and Water Pollution Control Federation (1998). Standard methods for the examination of water and wastewater, 20th ed., Washington, DC, USA.

Beamish FWH, Sa-ardrit P, Tongnunui S (2006) Habitat characteristics of the cyprinidae in small rivers in Central Thailand. Environmental Biology of Fishes 76:237-253.

Cravens JB (1982) Thermal effects. Journal of the Water Pollution Control Federation 54: 812-829.

Eaton GJ, Scheller RM (1996) Effects of climate warming on fish thermal habitat in streams of the United States. Limnology and Oceanography 41:1109-1115.

Gebrekiros ST (2016) Factors affecting stream fish community composition and habitat suitability. Journal of Aquaculture and Marine Biology 4:00076.
Islam, MS, Sarker, MJ, Yamamoto, T, Wahab, MA, Tanaka, M (2004) Water and sediment quality, partial mass budget and effluent $\mathrm{N}$ loading in coastal brackishwater shrimp farms in Bangladesh. Marine Pollution Bulletin 48:471-485.

Jaisuk C, Senanan W (2018a) Effects of landscape features on population genetic variation of a tropical stream fish, Stone lapping minnow, Garra cambodgiensis, in the upper Nan River drainage basin, northern Thailand. PeerJ 6:e4487

Jaisuk C, Senanan W (2018b) Effects of physical barriers on genetic variation of populations of stone lapping minnow, Garra cambodgiensis (Tirant, 1884), in Wa River, Nan Province, Thailand. Journal of Fisheries and Environment 42:53-65.

Johnson LL, Landahl JT, Kubin LA, Horness BA, Myers MS, Collier TK, Stein JE (1998) Assessing the effects of anthropogenic stressors on Puget Sound flatfish populations. Journal of Sea Research 39:125137.

Joradol U, Pornsopin P (2006) Breeding of Salween log sucker Garra fuliginosa Fowler. Technical paper (29/2006) (in Thai), Chiang Mai Inland Fisheries Research and Development Center. Available from: http://www.inlandfisheries.go.th/research/files/full/F292549.pdf

Kulabtong S, Mahaprom R (2016) Preliminary survey of hill stream fishes in upper cyber stream, outside Huai Kha Khaeng wildlife sanctuary, west Thailand. Biodiversity Journal 7:241-248.

Kullander SO, Fang F (2004) Seven new species of Garra (Cyprinidae: Cyprininae) from the Rakhine Yoma, southern Myanmar. Ichthyological Exploration of Freshwaters 15:257-278.

Lande R (1998) Anthropogenic, ecological and genetic factors in extinction and conservation. Researches on Population Ecology 40: 259-269.

Lothongkham A (2008) Species diversity of fishes in the Nan River basin (the Chao Phraya River system) in Nan Province, northern Thailand. MS Thesis, Kasetsart University, Bangkok, Thailand.

Mazlan AG, Samat A, Amirrudin A, Anita T (2007) Aspects of the biology of Garra cambodgiensis and Mystacoleucus marginatus (Cyprinidae) from Ulu Dungun Terengganu. Malaysian Applied Biology 36:76-72.

Mohseni O, Stefan HG, Eaton JG (2003) Global warming and potential changes in fish habitat in U.S. streams. Climatic Change 59:389-409.

Neville HM, Dunham JB, Peacock MM (2006) Landscape attributes and life history variability shape genetic structure of trout populations in a stream network. Landscape Ecology 21:901-916.

Pilger TJ, Gido KB, Propst DL, Whitney JE, Turner TF (2017) River network architecture, genetic effective size, and distributional patterns predict differences in genetic structure across species in a dryland stream fish community. Molecular Ecology 26:2687-2697.

Pornsopin P, Joradol U (2006) Induced spawning and nursing of stonelapping minnow Garra cambodgiensis (Tirant, 1884). Technical paper (21/2006) (in Thai). http://www.inlandfisheries.go.th/research/files/full/F212549.pdf 
Pornsopin R, Unsrisong G, Kantiyawong S, Muller-Belecke A, Horstgen-Schwark G (2004) Induced spawning and early development of stonelapping minnow, Garra cambodgiensis Tirant. Presented at the Rural Poverty Reduction through Research for Development Conference, Humboldt-Universitat $\mathrm{Zu}$ Berlin. http://www.tropentag.de/2004/abstracts/links/Pornsopin_6GblTnMr .pdf

Rainboth WJ (1996) Fishes of the Cambodian Mekong. Food and Agriculture Organization of the United Nations (FAO), Rome, Italy, $265 \mathrm{pp}$.

Smith HM (1945) The fresh-water fishes of Siam, or Thailand. Bulletin of the United States National Museum, 622 pp.
Sterling KA, Reed DH, Noonan BP, Warren ML (2012) Genetic effects of habitat fragmentation and population isolation on Etheostoma raneyi (Percidae). Conservation Genetics 13:859-872.

Taylor CM, Winston MR, Matthews WJ (1993) Fish speciesenvironment and abundance relationships in a Great Plains river system. Ecography 16:16-23.

Termvidchakorn A, Suksri S, Magtoon W (2016) Development and identification of Garra larvae in Thailand. Research and Knowledge 2:18-19.

Vidthayanon C. Karnasuta J. Nabhitabhata J (1997) Diversity of freshwater fishes in Thailand. Integrated Promotion Technology Co. Ltd., 103 pp. 